\title{
Bank Structure and Mortgage Rates: Reply
}

\author{
Michael L. Marlow
}

In Marlow (1982), I estimated a model of interest rate determination suggesting that interstate banking will, ceteris paribus, decrease competition in the mortgage market if it lowers the number of competing firms and increases deposit concentration levels. I identified statistically significant relations between mortgage rates and the number of firms, concentration ratios, unit banking dummy, and the number of commerc:al bank offices divided by the numbers of savings banks and savings and loan asscic:ations. Timothy Curry and John Rose argue that despite these "impressive" results, my empirical work involving the use of concentration ratios is flawed in two respects. In this Reply, I argue that Curry and Rose suffer from the same "flaw" in one case and introduce an arbitrary assumption in the other case.

Curry and Rose argue that it is incorrect not to consolidate bank subsidiaries of multibank holding companies (MBHC) when computing bank concenti ation data. The issue is whether or not MBHCs operate as integr ated, single entities similar to branches of banks. Curry and Rose argue in the affirmative, based on survey evidence in Rose (1978); Golembe (1978); and Whalen (1981).

Two points are in order. First, Rose (1978, p. 71) mentions that "... studies of the cperating policies of parent companies typically involve ad hoc survey work, the results of which often do not lend themselves co statistical analysis." Nonetheless, he argues that survey analysis suggests that MBHCs have witnessed an increasing degree of centralization over time. Second, there exist empirical studies on the issue that are not mentioned in Curry and Rose.' The studies of Ware (1975); Light (1975); Rhoades (1975); Goldberg (1976); Hoffman (1976); Whitehead and King (1976); and Rhoades (1977) find no evidence that MBHCs h ive exerted systematic effects on market competition. Evidel.ce of minor effects on competition, via small scale entry, is found in Heggestad and Rhoades (1976A) and Schweitzer and Greene (1977). It should be noted that small scale entry will not typically alter three-firm concentration ratios. Large scale entry effects on competition are found in Heggestad and Rhoades (1976B).

Which type of evidence are we to believe? The survey evidence suggests that we should consolidate and the empirical evidence suggests the opposite. While I prefer empirical over survey evidence, the issue remains unsettled. However, note that the reestimation of my model in Curry and Rose sheds some light on this point. Reestirna-

' For an e.:cellent sumr.sary of empirical studies, see Rhoades (1978).

Michael L. Marlow is a Financial Economist, Office of Monetary Policy Analysis, Department of the Treasury, and Associate Professor, Department of Economies, George Washington University, Wash:ng. ton, D.C. 2 C.J52. 
tion using consolidated data (in place of my unconsolidated data) shows that both the coefficient and significance level of the concentration variable decline. For example, the $t$-statistic for concentration meas'dred in terms of all firms falls from 2.86 [Eql-ation (3)] to 1.95 [Equation (5)]. As sugge sted in Curry and Rose, the assumption of centralized decision making may be wrong. This result is consistent with the above-menioned empirical studies suggesting that the MBHC movement has exerted little, if any, effect on market competition. In other wolds, Curry and Rose support the use of unconsolidated concentration data in market structure-performance studies.

Curry and Rose also argue that $I$ err in measuring firm concentration in terms of commercial banks alone and that their measure, which includes thrifts, is superior. While their measure is an interesting avenue to explore, its significance is dubious. Clearly, both of our measures suffer from the same problem; concentration in the mortgage market should control for relative market participation by all lenders. That is, a bitter measure would weigh the dominance of leading firms by their relative mortgage commitment activity in the SMSA. Since neither of our measures control for this problem, both of our studies are subject to the same error.

\section{Referencies}

Goldberg, L. G. Feb. 1976. Bank holding company acquisitions and their impact on market share. Journal of Monej, Credit and Banking 3:127-130.

Golembe Asscciates, Inc. 1978. Bank Holding Company Centraization Folicies. Washington, D.C.

Heggestad, A. A., and Rhoades, S. A. Nov. 1976A. Concentration and firm stability in commercial banking. Review of Economics and S!atistics 56:443-452.

Heggestad. A. A., and Rhoades, S. A. Fall 1976B. An analysis of changes in bank market structure. Allantic Economic Journal 4:64-69.

Hoffman, S. G. Jan. 1976. The impact of holding company affiliation on bank performance: A case study of two Florida multibank holding companies. Research Paper Series, Federal Reserve Bank of Atlanta.

Light, J. June 1975. Bank holding companies-Concentration levels in three-district states. Business Conditions. Federal Reserve Bank of Chicago.

Ma:low, M. L. 1982. Bank structure and mortgage rates: Implications for interstate banking. Journal of Economics and Business 34:135-142.

Rhoades, S. A. July 1975. The effect of bank holding company acquisitions of mortgage bankers on mortgage lending activity. journal of Business 48:344-348.

Rhoades, S. A. Spring 1977. The impact of foothold acquisitions on bank market structure. Antitrust Bulletin 22:119-128.

Rhoades, S. A. 1978. The effect of $b$ ink holding companies on competition. In The Banking Holding Company Movement to 1978 Board of Governors $\mathrm{c}$ the Federal Reserve System.

Rose, J. T. 1978. Bank holding companies as operational single entities. In The Bank Holding Company Movement to 1978 Board of Governors of the Federal Reserve System.

Schweitzer, P., and Greene, J. 1977. Greely in perspective. Staff Economic Studies 91, Board of Governors of the Federal Reserve System.

Ware, R. F. Nov. 1976. Bank concentration in Ohio. Economic Commentary. Federal Reserve Bank of Cleveland.

Whaler, G. Winter 1980-1981. Operational policies of multibank holding companies. Economic Review. Federal Reserve Bank of Cleveland.

Whitehead, D. D., and King. B. F. Apr. 1976. Multibank holding companies and local market concentration. Monthly Review. Federal Reserve Bank of Atlanta. 